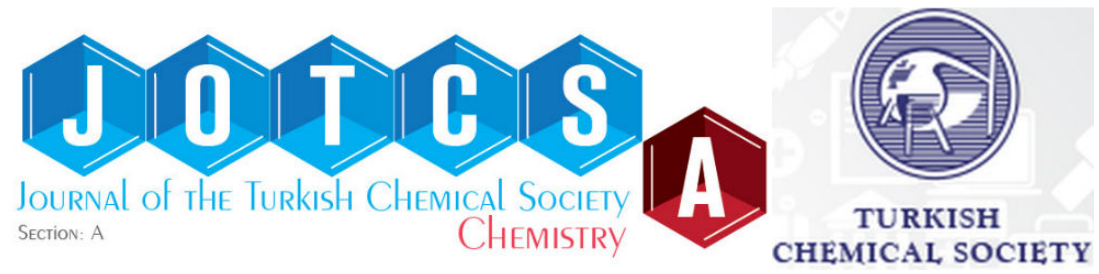

(This article was presented to the 28th National Chemistry Congress and submitted to JOTCSA as a full manuscript)

\title{
Evaluation of Energy Consumption in Electrochemical Oxidation of Acid Violet 7 Textile Dye Using Pt/Ir Electrodes
}

\author{
Bahadır K. Körbahti ${ }^{1 *}$ and Kezban Meltem Turan ${ }^{1}$ \\ ${ }^{1}$ Faculty of Engineering, Chemical Engineering Department, Mersin University, \\ Çiftlikköy 33343 Mersin, Turkey
}

\begin{abstract}
The effects of processing parameters were investigated on the electrochemical oxidation of textile dyeing wastewater containing Acid Violet 7 (AV7) at $\mathrm{Pt} / \mathrm{Ir}$ electrodes in the presence of $75 \% \mathrm{NaCl}+25 \% \mathrm{Na}_{2} \mathrm{CO}_{3}(\mathrm{w} / \mathrm{w})$ supporting electrolyte mixture in a batch electrochemical reactor. Experimental parameters were operated in the range of 300-1500 mg/L textile dye concentration, 4-20 g/L electrolyte concentration, 5-15 $\mathrm{mA} / \mathrm{cm}^{2}$ current density, and 20-60 ${ }^{\circ} \mathrm{C}$ reaction temperature. Energy consumption decreased with increasing textile dye concentration and electrolyte concentration, and decreasing the current density. In the study, energy consumption values were evaluated for textile dye decolorization ( $t=15 \mathrm{~min}$ ) and chemical oxygen demand (COD) removal ( $t=120 \mathrm{~min}$ ) as $2.7-23.3 \mathrm{kWh} / \mathrm{kg}$ dye decolorization and 50.9-317.9 $\mathrm{kWh} / \mathrm{kg}$ COD removal, respectively.
\end{abstract}

Keywords: Acid Violet 7, Electrochemical Wastewater Treatment, Energy Consumption, Pt/Ir Electrodes, Textile Dye.

Submitted: June 29, 2016. Revised: August 04, 2016. Accepted: August 17, 2016.

Cite this: Körbahti B, Turan K. Evaluation of Energy Consumption in Electrochemical Oxidation of Acid Violet 7 Textile Dye Using Pt/Ir Electrodes. Journal of the Turkish Chemical Society, Section A: Chemistry. 2016;3(3):75-92.

DOI: $10.18596 /$ jotcsa.31804.

* Corresponding author. E-mail: korbahti@mersin.edu.tr, korbahti@gmail.com. Phone: +90 (324) 3610001 ext. 7374, Fax: +90 (324) 3610032. 


\section{INTRODUCTION}

Textile wastewater is a hard-to-treat one due to its strong color, large amount of suspended solids, high chemical oxygen demand (COD), variable $\mathrm{pH}$, salt content, and high temperature. salt, auxiliary chemicals, and temperature-controlled dye bath conditions enhance and optimize the efficiency of the dyeing process (1). Typical dyeing processes use sodium chloride and sodium carbonate as common salts (2). Decolorization and removal of pollutants are major problems in dyeing process with salt elimination and water-use reduction as well (2). The main source of dyeing wastewater is rinsing processes and spent dye bath which typically contains auxiliary chemicals, salt, and residual dye (2). Wastewater from textile processes that can cause damage if not treated before discharging to the environment (3).

In the literature, treatment methods such as adsorption, biosorption, biodegradation, chemical oxidation, ozonization, coagulation, advanced oxidation, photocatalytic oxidation, electrocoagulation, and electrochemical oxidation have been investigated in order to remove various types of textile dyes, mainly photocatalytic degradation of Acid Violet 7 (AV7) dye was reported using $\mathrm{Fe}^{3+}-\mathrm{Al}_{2} \mathrm{O}_{3}(4,5), \mathrm{ZnO}(6)$, $\mathrm{Fe}^{3+}$-fire clay (7), $\mathrm{CdS}-\mathrm{SnO}_{2}(8), \mathrm{TiO}_{2}(9)$, and $\mathrm{AgBr}-\mathrm{ZnO}$ (10) photocatalysts.

Muthuvel and Swaminathan (4) stated that $\mathrm{Fe}^{3+}-\mathrm{Al}_{2} \mathrm{O}_{3}$ catalyst was efficient in the photoassisted Fenton mineralization of Acid Violet 7 dye in the presence of $\mathrm{H}_{2} \mathrm{O}_{2}$ and UV light. The authors determined the optimal conditions for the highest efficiency with $5 \times 10^{-4} \mathrm{M}$ dye, $1 \mathrm{~g} / \mathrm{L} \mathrm{Fe}^{3+}-\mathrm{Al}_{2} \mathrm{O}_{3}, 10 \mathrm{mmol} / \mathrm{L} \mathrm{H}_{2} \mathrm{O}_{2}$ and $\mathrm{pH}$ 3. In their following study, Muthuvel and Swaminathan (5) achieved 99\% COD reduction in UV process at $90 \mathrm{~min}$ and $99 \%$ COD reduction in solar process at $60 \mathrm{~min}$ with $5 \times 10^{-4} \mathrm{M}$ dye, $1 \mathrm{~g} / \mathrm{L} 25 \%$ $\mathrm{Fe}^{3+}-\mathrm{Al}_{2} \mathrm{O}_{3}$ catalyst, $10 \mathrm{mmol} \mathrm{H}_{2} \mathrm{O}_{2}$, and $8.1 \mathrm{~mL} / \mathrm{s}$ airflow rate. Krishnakumar and Swaminathan (6) used $\mathrm{ZnO}$ catalyst and they obtained $94.4 \%$ COD removal with $5 \times 10^{-4} \mathrm{M}$ dye at $2 \mathrm{~g} / \mathrm{L} \mathrm{ZnO}$ catalyst, $8.1 \mathrm{~mL} / \mathrm{s}$ airflow rate and $\mathrm{pH} 9$. In another study, the authors indicated that $\mathrm{AgBr}-\mathrm{ZnO}$ was found to be more efficient than commercial $\mathrm{ZnO}$ and prepared $\mathrm{ZnO}$ at $\mathrm{pH} 12$ for the mineralization of AV7 (10). Krishnakumar and Swaminathan (10) obtained $94.4 \%$ dye degradation with $5 \times 10^{-4} \mathrm{M}$ dye at $3 \mathrm{~g} / \mathrm{L} \mathrm{AgBr}$ $\mathrm{ZnO}$ catalyst, $8.1 \mathrm{~mL} / \mathrm{s}$ airflow rate and $\mathrm{pH} 12$. Muthuvel et al. (7) found that $26 \%$ $\mathrm{Fe}^{3+}$-fire clay $(\mathrm{Fe}-\mathrm{FC}$ ) catalyst exhibited the best photocatalytic activity at an initial $\mathrm{pH}$ 3 in the degradation of AV7 and its activity is significant up to $\mathrm{pH}$ 7. The authors 
achieved $77 \%$ AV7 dye degradation at 60 min with 20 mmol $\mathrm{H}_{2} \mathrm{O}_{2}$ at $\mathrm{pH} 7$ in solar light (7). Ghugal et al. (8) reported the photocatalytic activity of $\mathrm{CdS}-\mathrm{SnO}_{2}$ composite for the degradation of Acid Violet 7 dye. The authors obtained complete degradation and mineralization with $50 \mathrm{mg} / \mathrm{L}$ dye, $49 \mathrm{CdS}-\mathrm{SnO}_{2}$ composite by irradiation for $150 \mathrm{~min}$ (8). Fabbri et al., (9) investigated the photocatalytic degradation of Acid Violet 7 using $\mathrm{TiO}_{2}$ photocatalyst. The authors obtained complete AV7 degradation and mineralization at $120 \mathrm{~min}$ with $20 \mathrm{mg} / \mathrm{L}$ dye and $200 \mathrm{mg} / \mathrm{L} \mathrm{TiO}_{2}$ (9).

It is known that textile dyeing processes contribute very high amount of salt, auxiliary chemicals, and textile dye in wastewater effluent that conventional treatment systems may be inefficient for the effective treatment of industrial textile wastewater in removing both salt and color in order to meet discharge limits (2).

Electrochemical oxidation is a promising wastewater treatment method and replacing conventional processes in order to treat wastewater from industrial processes which are not easily biodegradable (2). Electrolysis reactions involve electrical charges moving between the electrolyte and the electrodes. The process depends on the use of direct electric current for the chemical changes in non-spontaneous oxidation/reduction reactions. The minimum amount of electrical energy that must be provided should be equal to the change in Gibbs free energy of the reaction and the losses in the system. In most cases, direct electrical input is larger than the enthalpic change of the reaction, so excess energy is released in the form of heat. Therefore, energy consumption in electrochemical processes should be optimized for its minimum use.

In this study, the electrochemical oxidation of Acid Violet 7 (AV7) textile dye using $\mathrm{Pt} / \mathrm{Ir}$ electrodes was investigated, and the effects of process variables such as current density, electrolyte concentration, initial dye concentration, and reaction temperature on electrochemical oxidation were analyzed for optimum energy consumption.

\section{MATERIALS AND METHODS}

\section{Chemicals and Materials}

Acid Violet 7 (AV7) textile dye (Sigma Aldrich) (Figure 1), $\mathrm{Na}_{2} \mathrm{CO}_{3}$ and $\mathrm{NaCl}$ (Merck) were purchased as extra pure grade. Textile dyeing wastewater was prepared synthetically using double distilled water. Double distilled water was obtained using 
ultrapure water system (Millipore Simplicity ${ }^{\circledR}$ UV) and water still (GFL-2008) with the resistivity of $18.2 \mathrm{M} \Omega \cdot \mathrm{cm} @ 25^{\circ} \mathrm{C}, \mathrm{TOC}<5 \mathrm{ppb}$.
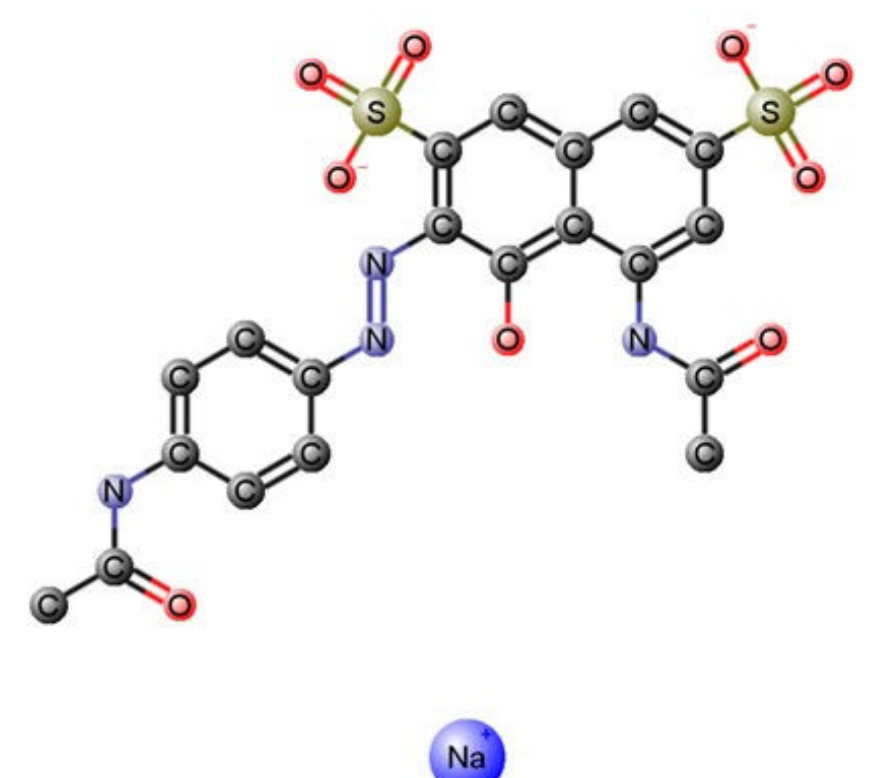

Figure 1. Molecular structure of Acid Violet 7 textile dye $\left(\mathrm{C}_{20} \mathrm{H}_{16} \mathrm{~N}_{4} \mathrm{Na}_{2} \mathrm{O}_{9} \mathrm{~S}_{2}\right)$

\section{EXPERIMENTAL}

The electrochemical reactor (DURAN ${ }^{\circledR}$ glass) used in this study has a heating and cooling jacket (Rettberg, Germany) as shown in Figure 2. Iron cathodes and Pt/Ir anodes were used as four pairs with $5 \mathrm{~mm}$ anode/cathode spacing. Total electrode surface area was $172 \mathrm{~cm}^{2}$. Pt/Ir anodes (Dr. Wieland, Germany) were in spiral shape with $90 \%$ Pt and 10\% Ir composition $(w=150 \mathrm{~mm}, \phi$ internal $=10 \mathrm{~mm}, \phi$ wire $=1.10 \mathrm{~mm})$. Iron electrodes were in cylindrical shape $(\phi=12.0 \mathrm{~mm})$ and purchased from local sources. Pt/Ir and iron electrodes were used as received without further preparation and treatment. Batch electrochemical system was equipped with programmable DC power supply (Goodwill PST-3201), heating/cooling tank (Lauda RE 630 S), mechanical mixer (Heidolph RZR 2021), and peristaltic pump (Cole Parmer Masterflex ${ }^{\circledR}$ RZ-77924$60)$. The reaction medium was mixed at $500 \mathrm{rpm}$. Influence of experimental parameters were operated as textile dye concentration, $300-1500 \mathrm{mg} / \mathrm{L}$; electrolyte concentration, 4-20 g/L; current density, 5-15 mA/ $\mathrm{cm}^{2}$; and reaction temperature, 20- 
$60^{\circ} \mathrm{C}$.

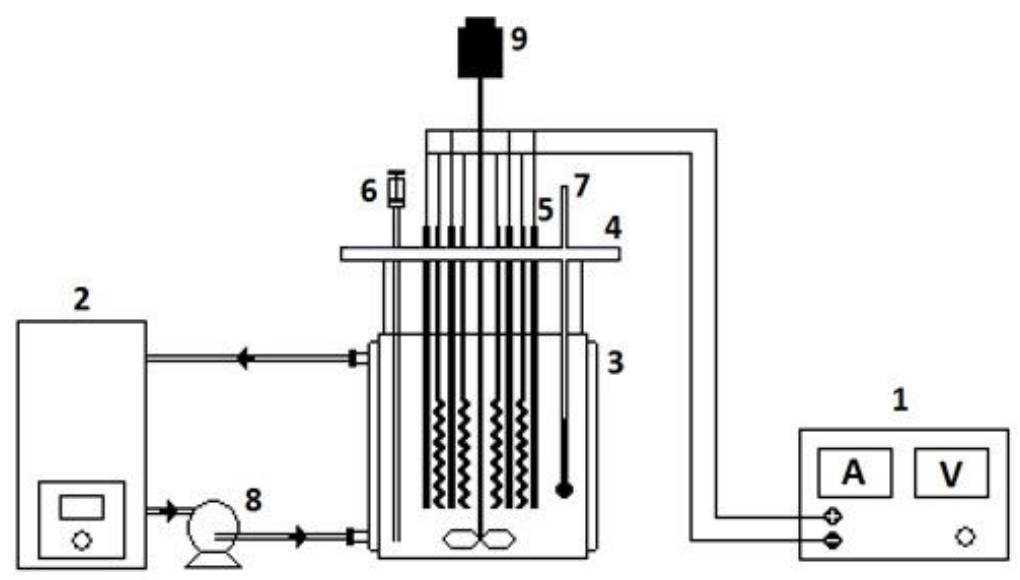

Figure 2. Batch electrochemical reactor system (1. programmable DC power supply, 2. heating/cooling tank, 3. batch electrochemical reactor, 4. reactor lid, 5. electrodes, 6. sampling cell, 7. thermometer, 8. heating/cooling pump, 9. mechanical mixer).

Samples in $10 \mathrm{~mL}$ volume were withdrawn from the reaction medium at 5 min time intervals for the analysis. Decolorization yield was analyzed using UNICO 4802 model UV/Vis double beam spectrophotometer at $490 \mathrm{~nm}$ wavelength. Merck Spectroquant ${ }^{\circledR}$ 14541 COD cell tests used for the COD analysis.

\section{RESULTS AND DISCUSSION}

Textile dye concentration, current density, electrolyte $\left(75 \% \mathrm{NaCl}+25 \% \mathrm{Na}_{2} \mathrm{CO}_{3}\right)$ concentration, and reaction temperature parameters were investigated on energy consumption in electrochemical oxidation of Acid Violet 7 (AV7) textile dye using Pt/Ir anodes. In this study, $75 \% \mathrm{NaCl}+25 \% \mathrm{Na}_{2} \mathrm{CO}_{3}(\mathrm{w} / \mathrm{w})$ mixture was used as a supporting electrolyte in order to increase the ionic conductivity of the reaction medium which are also main components in real textile industry wastewater (11).

Experimental results were analyzed using Design-Expert ${ }^{\circledR} 10$ software. Energy consumption values were calculated using Equations 1 and 2 (12).

$$
E_{D \%}=\frac{i V_{m} \Delta t}{C_{0}(0.01 d \%) V_{R}}
$$




$$
\mathrm{E}_{\mathrm{COD} \%}=\frac{\mathrm{iV}_{\mathrm{m}} \Delta \mathrm{t}}{\left(\mathrm{COD}_{\mathrm{o}}-\mathrm{COD}_{\mathrm{t}}\right) \mathrm{V}_{\mathrm{R}}}
$$

In Equations 1 and 2, $E_{D \%}, E_{C O D \%}, V_{m}, i, \Delta t, C_{0}, C O D$, $d \%$, and $V_{R}$ are energy consumption for dye decolorization ( $\mathrm{kWh} / \mathrm{kg}$ dye decolorization), energy consumption for COD removal ( $\mathrm{kWh} / \mathrm{kg}$ COD removal), mean cell voltage (volt), current (ampere), reaction time $(\mathrm{h})$, dye concentration $(\mathrm{g} / \mathrm{L})$, chemical oxygen demand $\left(\mathrm{g} \mathrm{O}_{2} / \mathrm{L}\right)$, dye decolorization percent, and electrolyte volume (L), respectively.

In the study depending on electrochemical reaction conditions, energy consumption values were outlined in Table 1 for Acid Violet 7 textile dye decolorization ( $t=15 \mathrm{~min}$ ) and COD removal ( $\mathrm{t}=120 \mathrm{~min}$ ) as $2.7-18.9 \mathrm{kWh} / \mathrm{kg}$ dye decolorization and 51.0-190.7 $\mathrm{kWh} / \mathrm{kg}$ COD removal, respectively. Energy consumption for dye decolorization was obtained as much lower than COD removal due to the degradation of azo bond is the first step of the electrochemical degradation of the textile dyes $(2,13)$.

Table 1. The influence of process parameters on energy consumption in electrochemical oxidation of textile dyeing wastewater containing Acid Violet 7 (AV7) using $\mathrm{Pt} / \mathrm{Ir}$ electrodes.

\begin{tabular}{|c|c|c|c|}
\hline Parameter & Reaction Conditions & $\begin{array}{c}\text { E }_{\mathrm{D} \%}(\mathbf{k W h} / \mathbf{k g} \text { dye } \\
\text { decolorization) } \\
(t=15 \mathrm{~min})\end{array}$ & $\begin{array}{l}\text { ECOD\% }(\mathrm{kWh} / \mathbf{k g} \\
\text { COD removal }) \\
(\mathrm{t}=120 \mathrm{~min})\end{array}$ \\
\hline $\begin{array}{l}\text { Textile dye } \\
\text { concentration }\end{array}$ & $\begin{array}{c}300-1500 \mathrm{mg} / \mathrm{L} \\
\text { (Electrolyte }=12 \mathrm{~g} / \mathrm{L}, \mathrm{J}=10 \\
\mathrm{~mA} / \mathrm{cm}^{2}, \mathrm{~T}=40^{\circ} \mathrm{C} \text { ) }\end{array}$ & $4.5-18.9$ & $83.5-169.8$ \\
\hline $\begin{array}{l}\text { Electrolyte } \\
\text { concentration }\end{array}$ & $\begin{array}{c}4-20 \mathrm{~g} / \mathrm{L} \\
(\mathrm{AV} 7=900 \mathrm{mg} / \mathrm{L}, \mathrm{J}=10 \\
\left.\mathrm{mA} / \mathrm{cm}^{2}, \mathrm{~T}=40^{\circ} \mathrm{C}\right)\end{array}$ & $5.9-15.0$ & $94.2-177.3$ \\
\hline Current density & $\begin{array}{c}5-15 \mathrm{~mA} / \mathrm{cm}^{2} \\
(\mathrm{AV} 7=900 \mathrm{mg} / \mathrm{L}, \\
\left.\text { Electrolyte }=12 \mathrm{~g} / \mathrm{L}, \mathrm{T}=40^{\circ} \mathrm{C}\right)\end{array}$ & $2.7-13.8$ & $51.0-190.7$ \\
\hline $\begin{array}{l}\text { Reaction } \\
\text { temperature }\end{array}$ & $\begin{array}{c}20-60^{\circ} \mathrm{C} \\
(\text { AV7 }=900 \mathrm{mg} / \mathrm{L} \\
\text { Electrolyte }=12 \mathrm{~g} / \mathrm{L}, \mathrm{J}=10 \\
\left.\mathrm{~mA} / \mathrm{cm}^{2}\right)\end{array}$ & $6.4-9.3$ & $97.7-113.3$ \\
\hline
\end{tabular}

In electrochemical treatment processes, organic pollutants could be removed from wastewater by indirect and direct mechanisms (13-17). Indirect oxidation occurs in the liquid bulk phase by the mediated oxidants, and direct oxidation at the anode surface (13-17). Most electrochemical processes are based on indirect oxidation because direct oxidation of organic pollutants are very slow on inert anodes due to limiting reactions and reaction kinetics $(18,19)$. 
Hydroxyl radicals are produced by the anodic discharge of water in indirect electrochemical oxidation of organic pollutants at Pt/Ir anodes. Hydroxyl radicals are adsorbed on the anode surface [S], and oxidize the organic material $(20,21)$. This reaction could also occur in acidic medium at high current densities (21). Oxidation process continues by the formation of hydroxyl radicals with anodic discharge of water molecules $(20,21)$.

$$
\begin{aligned}
& \mathrm{H}_{2} \mathrm{O}+\mathrm{S} \rightarrow \mathrm{S}\left[\mathrm{OH}^{\bullet}\right]+\mathrm{H}^{+}+\mathrm{e}^{-} \\
& \mathrm{R}+\mathrm{S}\left[\mathrm{OH}^{\bullet}\right] \rightarrow \mathrm{S}+\mathrm{RO}+\mathrm{H}^{+}+\mathrm{e}^{-}
\end{aligned}
$$

Chlorohydroxyl radicals are also produced with the presence of chloride ions, and adsorb on the active sites of the anode surface [S], and then oxidize the organic material $(20,21)$.

$$
\begin{aligned}
& \mathrm{H}_{2} \mathrm{O}+\mathrm{S}+\mathrm{Cl}^{-} \rightarrow \mathrm{S}\left[\mathrm{ClOH}^{\bullet}\right\rfloor+\mathrm{H}^{+}+2 \mathrm{e}^{-} \\
& \mathrm{R}+\mathrm{S}\left[\mathrm{ClOH}^{\bullet}\right\rfloor \rightarrow \mathrm{S}+\mathrm{RO}+\mathrm{H}^{+}+2 \mathrm{e}^{-}
\end{aligned}
$$

Therefore, electrochemical oxidation of textile dyeing wastewater results in decolorization with the formation of chlorohydroxyl and hydroxyl radicals. The reactions can also yield $\mathrm{O}_{2}, \mathrm{H}_{2} \mathrm{O}_{2}$, and $\mathrm{Cl}_{2}(20,21)$.

$$
\begin{aligned}
& \mathrm{H}_{2} \mathrm{O}+\mathrm{S}\left[\mathrm{OH}^{\circ}\right] \rightarrow \mathrm{S}+\mathrm{O}_{2}+3 \mathrm{H}^{+}+3 \mathrm{e}^{-} \\
& \mathrm{H}_{2} \mathrm{O}+\mathrm{S}\left[\mathrm{OH}^{\circ}\right] \rightarrow \mathrm{S}+\mathrm{H}_{2} \mathrm{O}_{2}+\mathrm{H}^{+}+\mathrm{e}^{-} \\
& \mathrm{H}_{2} \mathrm{O}+\mathrm{S}\left[\mathrm{ClOH}^{\circ}\right]+\mathrm{Cl}^{-} \rightarrow \mathrm{Cl}_{2}+\mathrm{S}+\mathrm{O}_{2}+3 \mathrm{H}^{+}+4 \mathrm{e}^{-}
\end{aligned}
$$

Indirect oxidation also occurs with the formation of $\mathrm{HOCl} / \mathrm{OCl}^{-}$redox mediators by the presence of $\mathrm{NaCl}$ which provides the anodic evolution of $\mathrm{Cl}_{2}$ (20-24). The percentage distribution of $\mathrm{HOCl} \mathrm{OCl}^{-}$depends on the solution $\mathrm{pH}$ (24). Chloride-chlorinehypochlorite-chloride cycle occurs in neutral to moderate $\mathrm{pH}$ solutions which maintain the initial concentration of chlorides stable (21).

$$
2 \mathrm{Cl}^{-} \rightarrow \mathrm{Cl}_{2}+2 \mathrm{e}^{-}
$$




$$
\begin{aligned}
& \mathrm{Cl}_{2}+\mathrm{H}_{2} \mathrm{O} \Leftrightarrow \mathrm{HOCl}+\mathrm{H}^{+}+\mathrm{Cl}^{-} \\
& \mathrm{HOCl} \Leftrightarrow \mathrm{H}^{+}+\mathrm{OCl}^{-} \\
& 6 \mathrm{OCl}^{-}+3 \mathrm{H}_{2} \mathrm{O} \rightarrow 2 \mathrm{ClO}_{3}^{-}+4 \mathrm{Cl}^{-}+6 \mathrm{H}^{+}+\frac{3}{2} \mathrm{O}_{2}+6 \mathrm{e}^{-} \\
& \mathrm{OCl}^{-}+\mathrm{H}_{2} \mathrm{O}+2 \mathrm{e}^{-} \rightarrow \mathrm{Cl}^{-}+2 \mathrm{OH}^{-}
\end{aligned}
$$

Figures 3-5 show the effect of process parameters on energy consumption in electrochemical oxidation of Acid Violet 7 textile dye that obtained by the quadratic models in Equations 15 and 16 using Design-Expert ${ }^{\circledR} 10$. Energy consumption model for dye decolorization evaluated using Equation 15 with $R^{2}=0.971, \operatorname{Radj}^{2}=0.947$ and signal/noise ratio $=26.553(\geq 4)$; and energy consumption model for COD removal evaluated using Equation 16 with $\mathrm{R}^{2}=0.981, \mathrm{Radj}^{2}=0.935$ and signal/noise ratio $=18.273$ $(\geq 4)$. These model coefficients indicating that the models are adequate and can be used for the mathematical analysis. In Equations 15 and 16, $\mathrm{E}_{\mathrm{D} \%}, \mathrm{E}_{\mathrm{COD} \%}, x_{1}, x_{2}, x_{3}$, and $x_{4}$ are energy consumption for dye decolorization ( $\mathrm{kWh} / \mathrm{kg}$ dye decolorization), energy consumption for COD removal ( $\mathrm{kWh} / \mathrm{kg}$ COD removal), Acid Violet 7 concentration $(\mathrm{mg} / \mathrm{L}), 75 \% \mathrm{NaCl}+25 \% \mathrm{Na}_{2} \mathrm{CO}_{3}$ electrolyte concentration $(\mathrm{w} / \mathrm{w})(\mathrm{g} / \mathrm{L})$, current density $\left(\mathrm{mA} / \mathrm{cm}^{2}\right)$, and reaction temperature $\left({ }^{\circ} \mathrm{C}\right)$, respectively.

$$
\begin{aligned}
& E_{D \%}=-0.021760 x_{1}-0.53535 x_{2}+4.84365 x_{3}+0.69701 x_{4}+4.32165 \times 10^{-4} x_{1} x_{2} \\
& -1.87807 \times 10^{-3} x_{1} x_{3}-1.10883 \times 10^{-4} x_{1} x_{4}-0.086221 x_{2} x_{3}-0.028898 x_{2} x_{4} \\
& -0.040203 x_{3} x_{4}+1.51628 \times 10^{-5} x_{1}^{2}+0.064540 x_{2}^{2}+0.042631 x_{3}^{2} \\
& +9.51469 \times 10^{-4} x_{4}^{2}-14.07577
\end{aligned}
$$

$$
\begin{aligned}
& E_{C O D \%}=-0.17811 x_{1}-33.09568 x_{2}+70.30423 x_{3}-0.33819 x_{4}+0.014291 x_{1} x_{2} \\
& -0.028618 x_{1} x_{3}+2.95185 \times 10^{-3} x_{1} x_{4}-1.02395 x_{2} x_{3}+0.35414 x_{2} x_{4} \\
& -0.68232 x_{3} x_{4}+5.71180 \times 10^{-5} x_{1}^{2}+0.46313 x_{2}^{2}+0.59078 x_{3}^{2} \\
& -1.63474 \times 10^{-3} x_{4}^{2}+33.19238
\end{aligned}
$$

(Eq. 16)

In Figure 3, energy consumption values were obtained as 3.7-31.1 kWh/kg dye decolorization and 83.3-314.7 kWh/kg COD removal between 300-1500 mg/L Acid Violet 7 concentration and 4-20 g/L $75 \% \mathrm{NaCl}+25 \% \mathrm{Na}_{2} \mathrm{CO}_{3}(\mathrm{w} / \mathrm{w}$ ) electrolyte mixture. Energy consumption decreased with increasing Acid Violet 7 concentration 
and electrolyte concentration as shown in Figure 3. Ionic conductivity of the reaction medium is a very important parameter in electrochemical cells for energy saving processes. Solution conductivity influences current efficiency, applied cell voltage, and electrical energy consumption. More energy is required for overcoming high ohmic resistance between anode and cathode when the ionic conductivity of the solution is low (25). The most common method used to increase the conductivity of the solution is by adding a small amount of supporting electrolyte that reduces the energy consumption during electrochemical treatment (25-27). Increasing electrolyte concentration decreases energy consumption (2). This behavior could be attributed to the increase of ionic conductivity of the reaction medium, and decrease of electrical resistance and applied cell voltage as well (2,28-30). Dalvand et al. (2011) studied the efficiency of electrocoagulation process using aluminum electrodes to treat synthetic wastewater containing Reactive Red 198. The authors reported that energy consumption strongly increases with increasing applied cell voltage. Petrović et al. (28) investigated the effect of $\mathrm{Na}_{2} \mathrm{SO}_{4}$ electrolyte concentration on the removal of crystal violet dye by electrochemical oxidation using platinum anode. The authors also found that the decolorization rate increased and the process energy consumption decreased with the increase of $\mathrm{Na}_{2} \mathrm{SO}_{4}$ concentration.

In Figure 3, the optimum region of lower than $10 \mathrm{kWh} / \mathrm{kg}$ dye decolorization and 95 $\mathrm{kWh} / \mathrm{kg}$ COD removal energy consumption was determined at above $1200 \mathrm{mg} / \mathrm{L}$ Acid Violet 7 and between $5.5-13.9 \mathrm{~g} / \mathrm{L} 75 \% \mathrm{NaCl}+25 \% \mathrm{Na}_{2} \mathrm{CO}_{3}$ electrolyte mixture. 

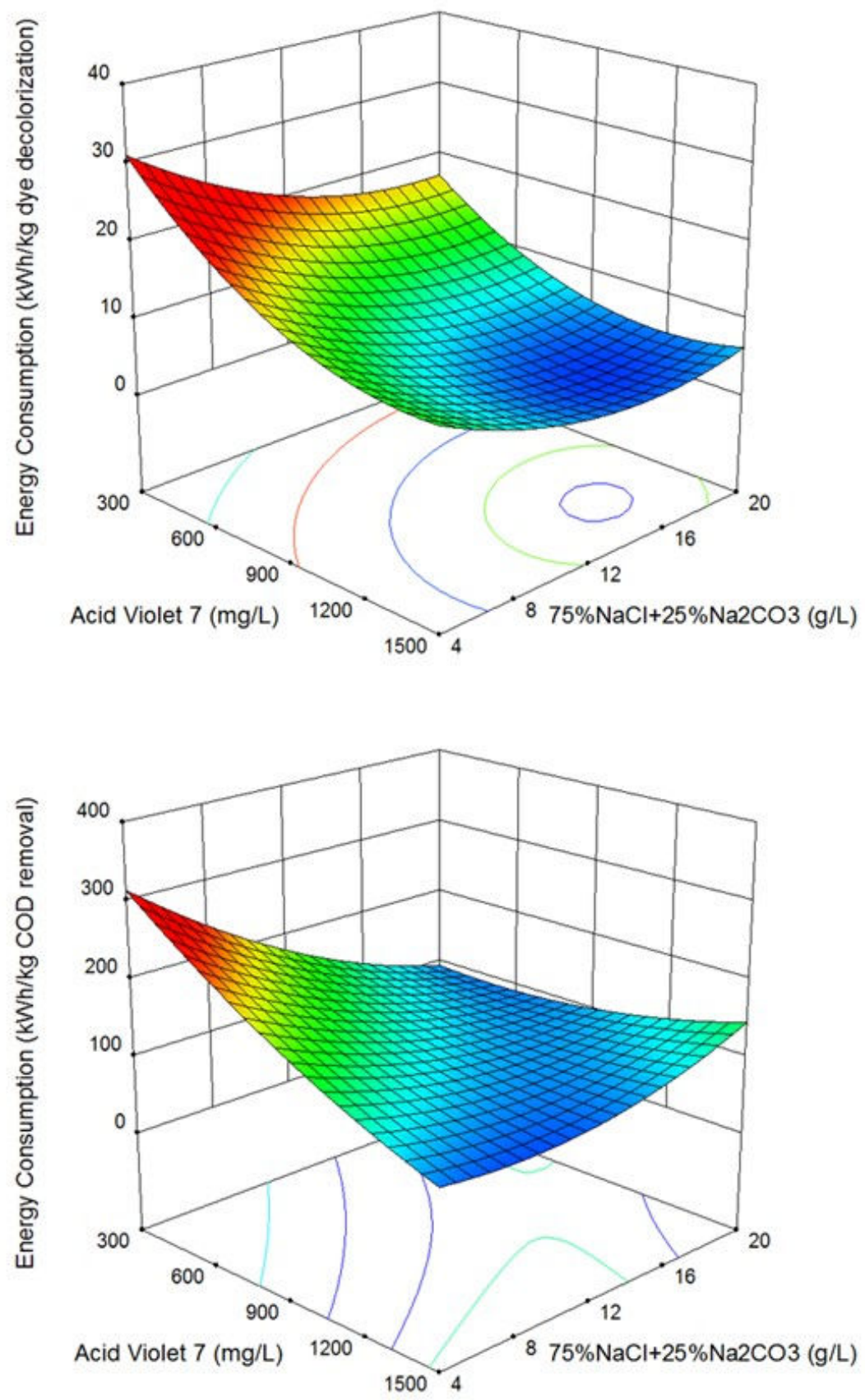

Figure 3. Effect of textile dye concentration and electrolyte concentration on energy consumption in electrochemical oxidation of Acid Violet 7 textile dye using Pt/Ir electrodes $\left(\mathrm{J}=10 \mathrm{~mA} / \mathrm{cm}^{2}, \mathrm{~T}=40^{\circ} \mathrm{C}, \mathrm{t}_{\mathrm{dye}}=15 \mathrm{~min}, \mathrm{t}_{\mathrm{COD}}=120 \mathrm{~min}\right)$. 

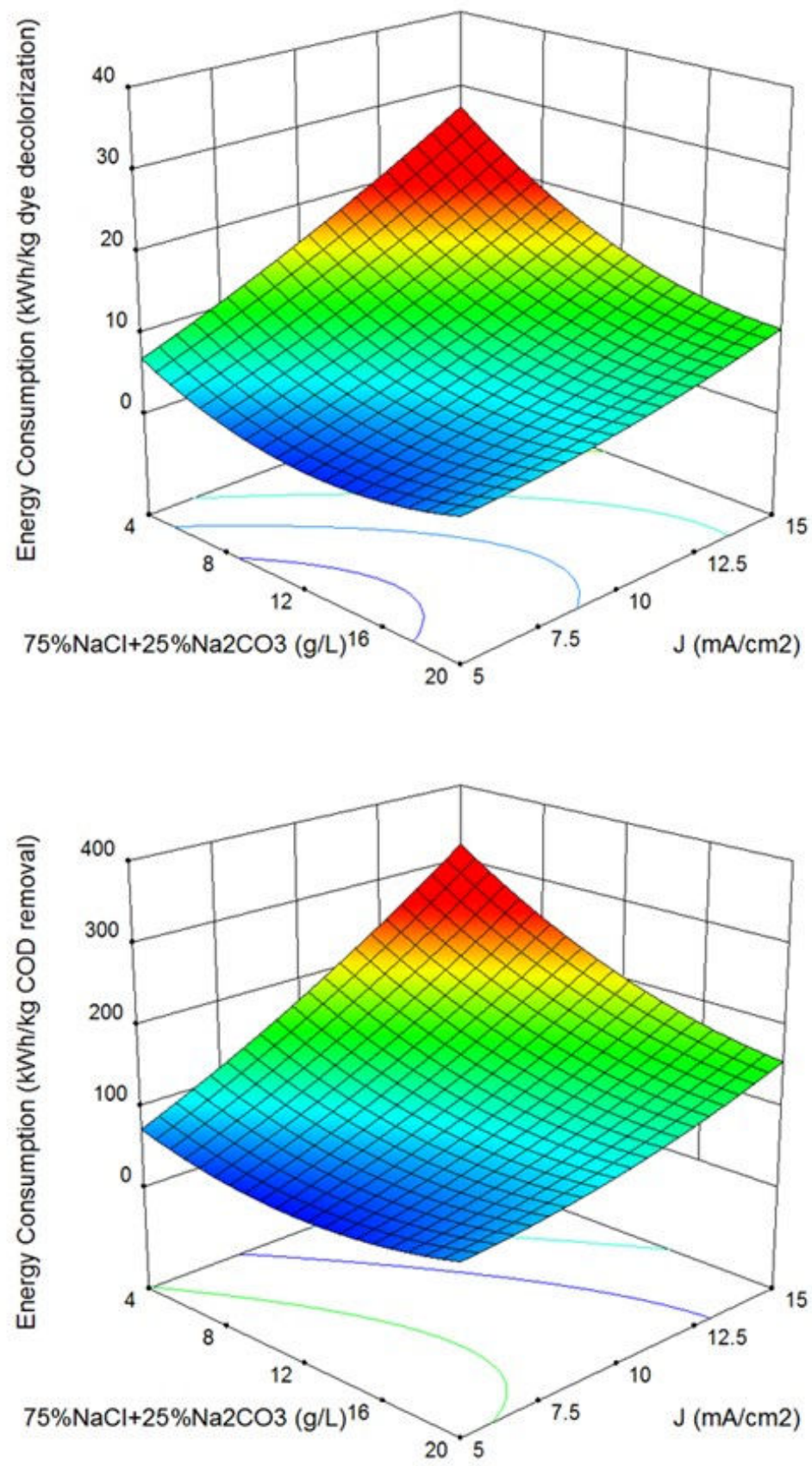

Figure 4. Effect of electrolyte concentration and current density on energy consumption in electrochemical oxidation of Acid Violet 7 textile dye using Pt/Ir electrodes $\left(A V 7=900 \mathrm{mg} / \mathrm{L}, \mathrm{T}=40^{\circ} \mathrm{C}, \mathrm{t}_{\mathrm{dye}}=15 \mathrm{~min}, \mathrm{t} \mathrm{COD}=120 \mathrm{~min}\right)$.

In Figure 4, energy consumption values were obtained as $1.3-27.4 \mathrm{kWh} / \mathrm{kg}$ dye decolorization and 43.7-312.2 kWh/kg COD removal between $5-15 \mathrm{~mA} / \mathrm{cm}^{2}$ current density and 4-20 g/L $75 \% \mathrm{NaCl}+25 \% \mathrm{Na}_{2} \mathrm{CO}_{3}(\mathrm{w} / \mathrm{w})$ electrolyte mixture. Energy 
consumption decreased with decreasing current density as shown in Figures 4 and 5 . Although increasing current density increases electrochemical oxidation efficiency, increasing current density causes an increase in the energy consumption according to Equations 1 and 2. In addition, applied current may be consumed by secondary reactions at very high cell voltages $(16,31)$. In Figure 4 , the optimum region lower than $10 \mathrm{kWh} / \mathrm{kg}$ dye decolorization and $95 \mathrm{kWh} / \mathrm{kg}$ COD removal energy consumption was determined at below $10.5 \mathrm{~mA} / \mathrm{cm}^{2}$ current density and between 10.1-14.6 $\mathrm{g} / \mathrm{L}$ $75 \% \mathrm{NaCl}+25 \% \mathrm{Na}_{2} \mathrm{CO}_{3}$ electrolyte mixture.

Energy consumption values were obtained as $1.3-20.8 \mathrm{kWh} / \mathrm{kg}$ dye decolorization and 2.4-284.9 kWh/kg COD removal between $5-15 \mathrm{~mA} / \mathrm{cm}^{2}$ current density and $20-60^{\circ} \mathrm{C}$ reaction temperature in Figure 5. Energy consumption decreased by decreasing the reaction temperature below $10.5 \mathrm{~mA} / \mathrm{cm}^{2}$ current density values as shown in Figure 5 , in which the optimum region of lower than $10 \mathrm{kWh} / \mathrm{kg}$ dye decolorization and 95 $\mathrm{kWh} / \mathrm{kg}$ COD removal energy consumption was determined below $10.5 \mathrm{~mA} / \mathrm{cm}^{2}$ current density and between $20-60^{\circ} \mathrm{C}$ reaction temperature. Therefore, optimum reaction temperature was determined in the mid of the experimental conditions as $40^{\circ} \mathrm{C}$.

The optimum region was determined for the energy consumption in electrochemical oxidation of Acid Violet 7 textile dye using Pt/Ir electrodes in Figure 6 . The shaded region in Figure 6 shows energy consumption of lower than $10 \mathrm{kWh} / \mathrm{kg}$ dye decolorization and $95 \mathrm{kWh} / \mathrm{kg}$ COD removal at optimum operating values of $40{ }^{\circ} \mathrm{C}$ reaction temperature and $1200 \mathrm{mg} / \mathrm{L}$ textile dye concentration. In this study, energy consumption values were obtained in a good agreement with the data previously reported in the literature for electrochemical wastewater treatment such as 2.6-90.0 $\mathrm{kWh} / \mathrm{kg}$ dye decolorization and $1.2-253.3 \mathrm{kWh} / \mathrm{kg}$ COD removal $(12,15,28)$. The optimum operating region was found to be applicable for the electrochemical treatment of industrial textile wastewater. 

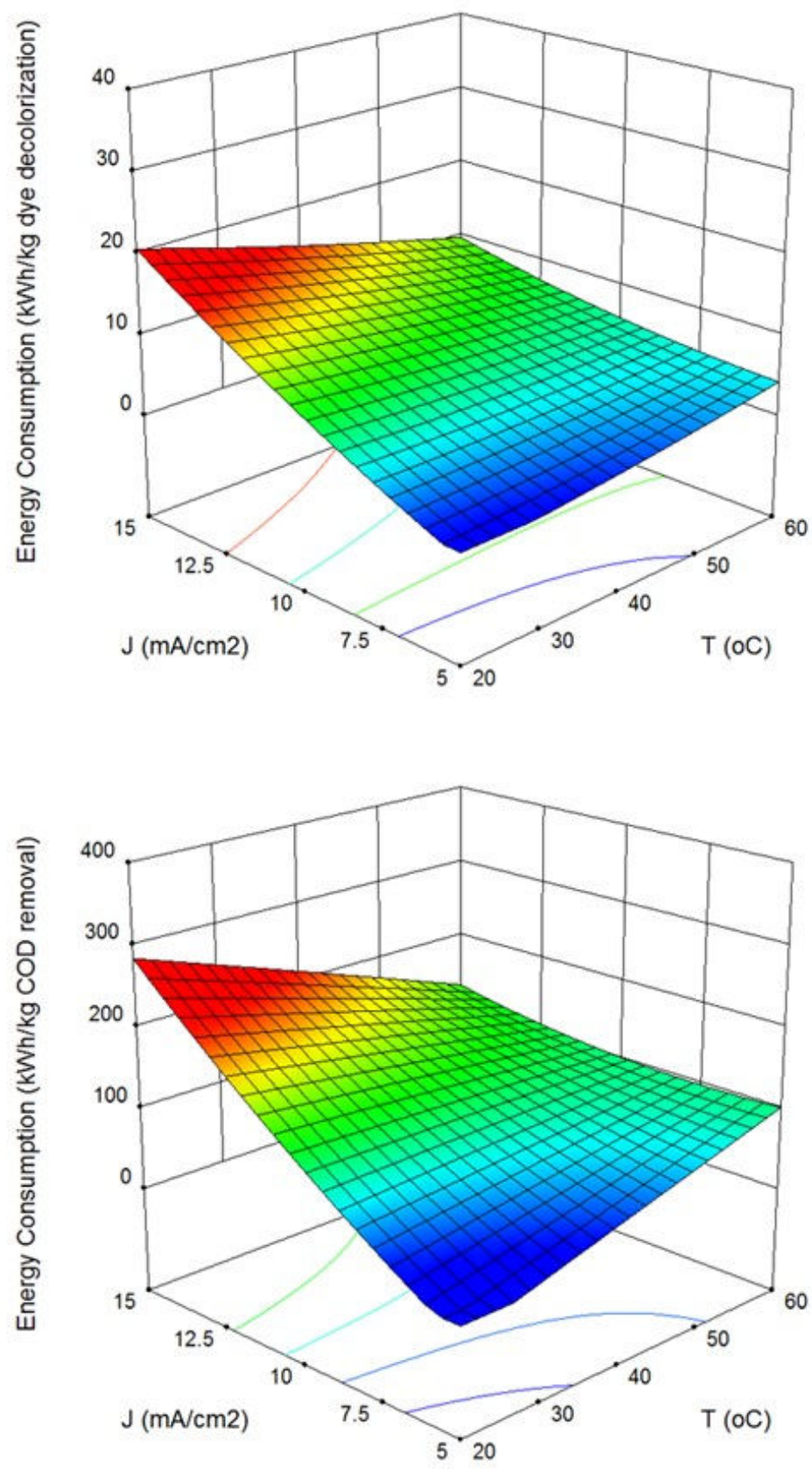

Figure 5. Effect of current density and reaction temperature on energy consumption in electrochemical oxidation of Acid Violet 7 textile dye using Pt/Ir electrodes (AV7 $=900$ $\mathrm{mg} / \mathrm{L}$, Electrolyte $=12 \mathrm{~g} / \mathrm{L}, \mathrm{t}_{\text {dye }}=15 \mathrm{~min}, \mathrm{t}_{\mathrm{COD}}=120 \mathrm{~min}$ ). 


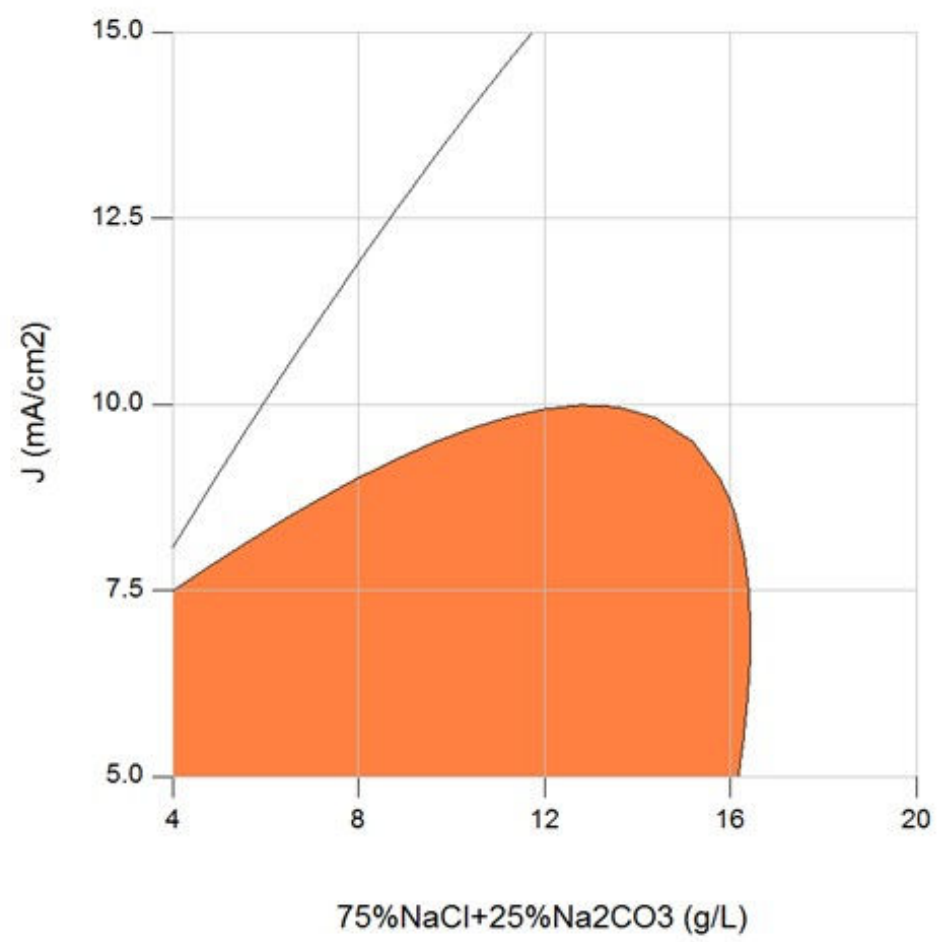

Figure 6. Optimum region for energy consumption in electrochemical oxidation of Acid Violet 7 textile dye using Pt/Ir electrodes $\left(A V 7=1200 \mathrm{mg} / \mathrm{L}, \mathrm{T}=40^{\circ} \mathrm{C}, \mathrm{t}_{\mathrm{dye}}=15 \mathrm{~min}\right.$, $\left.\mathrm{t}_{\mathrm{COD}}=120 \mathrm{~min}\right)$.

\section{CONCLUSIONS}

The evaluation of energy consumption in electrochemical oxidation of Acid Violet 7 textile dye was investigated using $\mathrm{Pt} / \mathrm{Ir}$ anodes in the presence of $75 \% \mathrm{NaCl}+25 \%$ $\mathrm{Na}_{2} \mathrm{CO}_{3}$ supporting electrolyte mixture. Energy consumption decreased with increasing textile dye concentration and electrolyte concentration, and decreasing the current density. Depending on electrochemical reaction conditions, energy consumption values were evaluated for textile dye decolorization $(t=15 \mathrm{~min})$ and COD removal $(t=120$ $\mathrm{min}$ ) as 2.7-18.9 kWh/kg dye decolorization and 51.0-190.7 kWh/kg COD removal, respectively. The optimum region was determined for the energy consumption in electrochemical oxidation of Acid Violet 7 textile dye using Pt/Ir electrodes at lower than $10 \mathrm{kWh} / \mathrm{kg}$ dye decolorization and $95 \mathrm{kWh} / \mathrm{kg}$ COD removal. In this study, energy consumption values were obtained in a good agreement with the data reported in the literature. Experimental findings showed that electrochemical oxidation could be an alternative as a treatment method for textile wastewater effluent. 


\section{ACKNOWLEDGEMENTS}

This project was supported by Mersin University Scientific Research Projects Center (MEÜ BAP) with Grant No. 2015-TP2-1037.

\section{REFERENCES}

1. US EPA. EPA Office of Compliance Sector Notebook Project: Profile of the Textile Industry. 1997. EPA310R97009.

2. Körbahti BK. Response surface optimization of electrochemical treatment of textile dye wastewater. Journal of Hazardous Materials. 2007;145(1-2):277-86. DOI: 10.1016/j.jhazmat.2006.11.031.

3. US EPA. Best Management Practices for Pollution Prevention in the Textile Industry. 1996. EPA625R96004.

4. Muthuvel I, Swaminathan M. Photoassisted Fenton mineralisation of Acid Violet 7 by heterogeneous Fe(III)-Al2O3 catalyst. Catalysis Communications 8 (2007) 981-6. DOI: 10.1016/j.catcom.2006.10.015.

5. Muthuvel I, Swaminathan M. Highly solar active Fe(III) immobilised alumina for the degradation of Acid Violet 7. Solar Energy Materials \& Solar Cells. 2008;92:857-63. DOI: 10.1016/j.solmat.2008.02.007.

6. Krishnakumar B, Swaminathan M. Influence of operational parameters on photocatalytic degradation of a genotoxic azo dye Acid Violet 7 in aqueous ZnO suspensions. Spectrochimica Acta Part A. 2011; 81:739- 44. DOI: 10.1016/j.saa.2011.07.019.

7. Muthuvel I, Krishnakumar B, Swaminathan M. Solar active fire clay based hetero-Fenton catalyst over a wide $\mathrm{pH}$ range for degradation of Acid Violet 7. Journal of Environmental Sciences. 2012;24(3):529-35. DOI: 10.1016/S1001-0742(11)60754-7.

8. Ghugal SG, Umare SS, Sasikala R. A stable, efficient and reusable CdS-SnO2 heterostructured photocatalyst for the mineralization of Acid Violet 7 dye. Applied Catalysis A: General. 2015;496:25-31. DOI: 10.1016/j.apcata.2015.02.035.

9. Fabbri D, Calza $P$, Prevot AB. Photoinduced transformations of Acid Violet 7 and Acid Green 25 in the presence of TiO2 suspension. Journal of Photochemistry and Photobiology A: Chemistry. 2010;213:14-22. DOI: 10.1016/j.jphotochem.2010.04.014.

10. Krishnakumar B, Swaminathan M. Photodegradation of Acid Violet 7 with AgBr-ZnO under highly alkaline conditions. Spectrochimica Acta Part A: Molecular and Biomolecular Spectroscopy. 2012;99:160-5. DOI: 10.1016/j.saa.2012.08.077.

11. Körbahti BK, Tanyolaç A. Electrochemical treatment of simulated textile wastewater with industrial components and Levafix Blue CA reactive dye: Optimization through response surface methodology. Journal of Hazardous Materials. 2008;151(2-3):422-31.

12. Körbahti BK, Artut K, Geçgel C, Özer A. Electrochemical decolorization of textile dyes and removal of metal ions from textile dye and metal ion binary mixtures. Chemical Engineering Journal. 2011;173(3):677-88. DOI: 10.1016/j.cej.2011.02.018.

13. Comninellis C, Chen G. Electrochemistry for the environment. Springer; 2010. ISBN: 
9780387369228.

14. Brillas E, Martínez-Huitle CA. Decontamination of wastewaters containing synthetic organic dyes by electrochemical methods. An updated review. Applied Catalysis B: Environmental. 2015;166:603-43. DOI: 10.1016/j.apcatb.2014.11.016.

15. Körbahti BK, Artut K. Electrochemical oil/water demulsification and purification of bilge water using Pt/Ir electrodes. Desalination. 2010;258(1-3):219-28. DOI: 10.1016/j.desal.2010.03.008.

16. Körbahti BK, Taşyürek S. Electrochemical oxidation of ampicillin antibiotic at borondoped diamond electrodes and process optimization using response surface methodology. Environmental Science and Pollution Research. 2015;22(5):3265-78. DOI: 10.1007/s11356014-3101-7.

17. Panizza M, Cerisola G. Direct And Mediated Anodic Oxidation of Organic Pollutants. Chemical Reviews. 2009;109(12):6541-69. DOI: 10.1021/cr9001319.

18. Tarr MA. Chemical Degradation Methods for Wastes and Pollutants. CRC Press; 2003. ISBN: 9780824743079.

19. Rajeshwar K, Ibanez JG. Environmental Electrochemistry. Academic Press; 1997. ISBN: 9780123887320.

20. Vlyssides AG, Israilides CJ, Loizidou M, Karvouni G, Mourafeti V. Electrochemical treatment of vinasse from beet molasses. Water Science and Technology. 1997;36(2-3):271-8. DOI: $10.1016 / \mathrm{S} 0273-1223(97) 00398-3$.

21. Israilides C, Vlyssides A, Mourafeti V, Karvouni G. Olive oil wastewater treatment with the use of an electrolysis system. Bioresource Technology. 1997;61(2):163-70. DOI: 10.1016/S0960-8524(97)00023-0.

22. Do J-S, Yeh W-C. Paired electrooxidative degradation of phenol with in situ electrogenerated hydrogen peroxide and hypochlorite. Journal of Applied Electrochemistry. 1996;26(6):673-8. DOI: 10.1007/BF00253467.

23. Lin SH, Shyu CT, Sun MC. Saline wastewater treatment by electrochemical method. Water Research. 1998;32(4):1059-66. DOI: 10.1016/S0043-1354(97)00327-8.

24. Tchobanoglous G, Burton FL, Stensel HD. Wastewater Engineering: Treatment and Reuse. McGraw-Hill, 2004. ISBN: 9780071241403.

25. Chou WL, Wang CT, Chang SY. Study of COD and turbidity removal from real oxide-CMP wastewater by iron electrocoagulation and the evaluation of specific energy consumption. Journal of Hazardous Materials. 2009;168:1200-7. DOI: 10.1016/j.jhazmat.2009.02.163.

26. Lin SH, Chang CC. Treatment of landfill leachate by combined electro-Fenton oxidation and sequencing batch reactor method. Water Research. 2000;34(17):4243-9. DOI: $10.1016 /$ S0043-1354(00)00185-8.

27. Wang C-T. Decolorization of Congo Red with Three-Dimensional Flow-By Packed-Bed Electrodes. Journal of Environmental Science and Health Part A-Toxic/Hazardous Substances \& Environmental Engineering. 2003;A38(2):399-413. DOI: 10.1081/ESE-120016903.

28. Petrovi M, Miljkovi M, Boji A, Stepanovi J, Stamenkovi M. The Influence of the Background Electrolyte Concentration on the Removal of Crystal Violet by Electrochemical Oxidation on the Platinum Anode. Advanced technologies. 2013;2(1):41-4.

29. İrdemez Ş, Tosunoglu NDV. The effects of supporting electrolyte type and concentration 
Körbahti and Turan, JOTCSA. 2016; 3(3): 75-92.

on the phosphate removal from wastewater by electrocoagulation with aluminum plate electrodes. Iğdır University Journal of the Institute of Science and Technology. 2011;1(2):35-40.

30. Dalvand A, Gholami M, Joneidi A, Mahmoodi NM. Dye Removal, Energy Consumption and Operating Cost of Electrocoagulation of Textile Wastewater as a Clean Process. CLEAN - Soil, Air, Water. 2011;39 (7):665-72. DOI: 10.1002/clen.201000233.

31. Shen ZM, Wu D, Yang J, Yuan T, Wang WH, Jia JP. Methods to improve electrochemical treatment effect of dye wastewater. Journal of Hazardous Materials. 2006;131(1-3):90-7. DOI: 10.1016/j.jhazmat.2005.09.010. 
Türkçe Öz ve Anahtar Kelimeler

\section{Pt/Ir Elektrotlar Kullanarak Asit Viyole 7 Tekstil \\ Boyasının Elektrokimyasal Yükseltgenmesinde Enerji Tüketiminin Değerlendirilmesi}

Bahadır K. Körbahti ${ }^{1 *}$ and Kezban Meltem Turan ${ }^{1}$

Öz: \%75 NaCl + \%25 $\mathrm{Na}_{2} \mathrm{CO}_{3}(\mathrm{w} / \mathrm{w})$ varlığında Pt/Ir elektrotlarda Asit Viyole 7 (AV7) içeren tekstil boyama atık suyunun elektrokimyasal yükseltgenmesinde proses parametreleri kesikli elektrokimyasal reaktörde incelenmiştir. Deneysel parametreler 300-1500 mg/L tekstil boya derişimi, $4-20 \mathrm{~g} / \mathrm{L}$ elektrolit derişimi, $5-15 \mathrm{~mA} / \mathrm{cm}^{2}$ akım yoğunluğu ve $20-60{ }^{\circ} \mathrm{C}$ tepkime sıcaklığı kullanılarak yürütülmüştür. Enerji tüketimi artan tekstil boyar madde derişimi, elektrolit derişimi ve ve azalan akım yoğunluğu ile artmıştır. Çalışmada, tekstil boya giderimi ( $t=15$ dak) ve kimyasal oksijen ihtiyacı (KOİ) giderimi ( $t=120$ dak) için enerji tüketim değerleri sırasıyla 2,7 - 23,3 kWh-kg boya derişimi ve 50,9 - 317,9 kWh/kg KOİ giderimi olarak bulunmuştur.

Anahtar kelimeler: Asit Viyole 7, Elektrokimyasal Atık Su Islahı, Enerji Tüketimi, Pt/Ir Elektrotlar, Tekstil Boyarmaddesi.

Sunulma: 29 Haziran 2016. Düzeltme: 04 Ağustos 2016. Kabul: 17 Ağustos 2016. 